\title{
ANALISIS FAKTOR-FAKTOR YANG MEMPENGARUHI KETERLAMBATAN SURAT PERTANGGUNGJAWABAN KEUANGAN PADA PEMERINTAH KABUPATEN BOVEN DIGOEL
}

\author{
Nimrod Basna ${ }^{2}$ \\ basnanimrod@gmail.com \\ Elita Bharanti ${ }^{3}$ \\ ebonifasia@yahoo.com \\ Juliana Waromi ${ }^{4}$ \\ julianwr@gmail.com
}

\begin{abstract}
This paper studied the effect of human resources, regional budgeting planning and delays of third parties financial reporting to regional letters of financial accountability postponement. The study was conducted in Government Work Units in Boven Digoel Regency. There were 23 Work Units which involved in the study. There were 97 respondents using purposive sampling technique. An empirical test was run using Multiple Regression Model to test research hypotheses.

The study found that human resources and regional budgeting planning significantly impacted on the delays of letter of financial accountability in Boven Digoel Regency. In addition, the delays of third parties financial reporting were not supported to have impact on regional letters of financial accountability postponement in the Regency.
\end{abstract}

Key words: Human Resources, Regional Budgeting Planning, Delays of third parties financial reporting

\section{PENDAHULUAN}

Perubahan paradigma yang terjadi di Indonesia melahirkan, Undangundang (UU) No. 22 Tahun 1999 tentang Pemerintah Daerah yang direvisi menjadi UU No. 32 Tahun 2004 dan diubah dengan Peraturan Perundang-undangan (Perpu) No. 3 Tahun 2005 serta UU No. 25 tentang Perimbangan Keuangan antara Pemerintah Pusat dan Daerah

\footnotetext{
${ }^{2}$ Alumni Mahasiswa Magister Keuangan Daerah Universitas Cenderawasih

${ }^{3}$ Staf Dosen Jurusan Manajemen Fakultas Ekonomi dan Bisnis Universitas Cenderawasih

${ }^{4}$ Staf Dosen Jurusan Akuntansi Fakultas Ekonomi dan Bisnis Universitas Cenderawasih
} 
yang direvisi menjadi UU No. 33 Tahun 2004, menjadi tonggak awal dari otonomi daerah. Otonomi daerah merupakan upaya pemberdayaan daerah dalam pengambilan keputusan daerah berkaitan dengan pengelolaan sumber daya yang dimiliki sesuai dengan kepentingan, prioritas, dan potensi daerah tersebut. Dengan pemberian otonomi daerah kabupaten dan kota, pengelolaan keuangan sepenuhnya berada ditangan Pemerintah Daerah.

Beberapa peraturan terkait dengan implementasi otonomi daerah yang telah dikeluarkan adalah berkenaan dengan pengelolaan keuangan daerah dikeluarkan Peraturan Pemerintah No 58 tahun tentang Pengelolaan Keuangan Daerah. Sebagai tindak lanjut PP No. 58 tahun 2005, Menteri Dalam Negeri telah mengeluarkan Peraturan Menteri Dalam Negeri (Permendagri) No 13 Tahun 2006 tentang Pedoman Pengelolaan Keuangan Daerah, dan terakhir telah direvisi dengan Permendagri No. 59/2007 tentang Perubahan Atas Permendagri No. 13/2006 tentang Pedoman Pengelolaan Keuangan Daerah.

Peraturan ini khusus mengatur mengenai pedoman pengelolaan keuangan daerah yang baru, sesuai arah reformasi tata kelola keuangan negara/daerah. Perubahan yang sangat mendasar dalam peraturan ini adalah bergesernya fungsi Ordonancering dari Badan/bagian/biro Keuangan ke setiap Satuan Kerja Perangkat Daerah (SKPD), dan SKPD sebagai accounting entity berkewajiban untuk membuat laporan keuangan SKPD serta penegasan bahwa Bendahara Pengeluaran sebagai Pejabat Fungsional.

Untuk melaksanakan itu semua maka semangat desentralisasi, demokratisasi, transparansi dan akuntabilitas menjadi sangat penting dalam rangka mewarnai proses penyelenggaraan pemerintahan pada umumnya dan proses pengelolaan keuangan daerah pada khususnya.

Untuk mewujudkan pengelolaan keuangan daerah seperti yang 
disyaratkan tersebut di atas, maka sebagai penanggung jawab keuangan daerah atau pemegang kekuasaan umum pengelolaan keuangan daerah yang dijabat oleh Kepala Daerah mempunyai kewajiban menyampaikan pertanggungjawaban keuangan sebegai salah satu bentuk akuntabilitas publik. Pelaksanaan pengelolaan Keuangan Daerah, seorang kepala daerah tidak dapat dengan mudah dan tepat waktu menyampaikan pertanggungjawaban tentang keadaan keuangan daerah. Yang menjadi hambatan utama dalam penyampaian laporan keuangan seperti yang ditentukan dalam peraturan tersebut adalah keterlambatan laporan realisasi anggaran penggunaan dana dari setiap unit kerja. Keterlambatan pertanggungjawaban salah satu instansi berarti akan membawa akibat pada keterlambatan pertanggungjawaban keuangan Kepala Daerah.

Data yang ada tentang keterlambatan para bendaharawan tersebut di Kabupaten Boven Digoel selama kurun waktu 3 (tiga) tahun, yaitu Tahun Anggaran 2010 s/d 2012 bahwa jumlah bendaharawan yang terlambat membuat surat pertanggungjawaban (SPJ) baik untuk bendahara penerimaan maupun bendahara pengeluaran menunjukan angka cukup besar. Jumlah keterlambatan ini semakin besar dari tahun ke tahun. Dengan demikian perlu dicarikan jalan keluarnya sehingga tidak mengalami keterlambatan.

Jumlah bendaharawan yang mengalami keterlambatan dalam pembuatan laporan keuangan tersebut bila dibandingkan dengan jumlah bendaharawan yang ada di Kabupaten Boven Digoel pada tahun 2010 sampai tahun 2012 mengalami kenaikan jumlah bendahara yang mengalami keterlambatan yang semakin meningkat dari tahun ke tahun hal ini bisa dilihat dari tahun 2010 sebanyak 29 orang bendahara atau sebesar 29.90 \%. Sedangkan dari tahun 2010 ke tahun 2011 terjadi peningkatan menjadi 33 orang bendahara atau sebesar $34,02 \%$, dan selanjutnya terjadi peningkatan lagi pada tahun 2012 menjadi 35 
orang bendahara atau sebesar $36,08 \%$. Secara kumulatif selama 3 (tiga) tahun terakhir keterlambatan pada bendahara di Kabupaten Boven Digoel cukup besar yaitu $49 \%$.

Kajian yang dilakukan Indrijawati (2008) tentang faktor-faktor penyebab keterlambatan surat pertanggungjawaban belanja dipemerintah daerah menemukan bahwa faktor penyebab keterlambatan penyampaian surat pertanggungjawaban (SPJ) pada dasarnya terkait 2 aspek yaitu: aspek sumber daya manusia dan aspek teknis yang terdiri dari aspek perencanaan APBD dan aspek rekanan yang terlambat menyampaikan bukti pengeluaran.

Realita yang terjadi pada Kabupaten Boven Digoel dimana faktor yang menjadi pemicu keterlambatan surat pertanggungjawaban (SPJ) dikarenakan oleh beberapa faktor diantaranya yaitu: kurangnya sumber daya manusia yang dimiliki, selanjutnya kurangnya pelatihan dan pendidikan terkait keuangan yang mendukung dalam penyelesaian tupoksi pegawai, penempatan pegawai yang kurang sesuai dengan latar belakang pendidikan yang mendukung dalam penyelesaian tupoksi, faktor sangat dominan juga adalah politik, system pengelolaan keuangan yang belum memadai dan sarana dan prasarana yang belum memadai juga sebagai pemicu keterlambatan surat pertanggungjawaban (SPJ) di daerah Kabupaten Boven Digoel.

Realita diatas sejalan dengan kajian yang dilakukan oleh Indrijawati (2010) yang mengkaji faktor-faktor penyebab keterlambatan surat pertanggungjawaban (SPJ) Belanja di Pemerintah Daerah, hasil kajian menunjukan bahwa faktor-faktor penyebab keterlambatan penyampaian surat pertanggungjawaban terkait atas dua aspek yaitu: aspek sumberdaya manusia, dan aspek teknis yang terdiri dari: aspek perencanaan APBD dan aspek rekanan yang terlambat menyampaikan bukti pengeluaran. Hal ini didukung oleh kajian-kajian yang dilakukan 
Halim (2006).

Berdasarkan fenomena diatas maka penulis termotivasi melakukan penelitian ini yang dilakukan pada satuan kerja perangkat daerah (SKPD) yang berada di Kabupaten Boven Digoel, untuk menguji dan menganalisis apakah faktor SDM, perencanaan ABPD dan rekanan mempengaruhi keterlambatan penyampaian surat pertanggungjawaban (SPJ). Dengan tuisan ini diharapkan dapat disusun rekomendasi dan langkah-langkah yang diperlukan bagi para perencana di bidang keuangan dan pelaksana kegiatan keuangan daerah, dalam upaya mengatasi keterlambatan pelaporan keuangan di Lingkungan Pemerintah Kabupaten Boven Digoel, dan dapat dijadikan sebagai bahan masukan bagi setiap instansi unit kerja di Lingkungan Pemerintah Kabupaten Boven Digoel dalam memahami tentang arti pentingnya suatu Laporan Pertanggungjawaban Keuangan yang dibuat dan disampaikan tepat pada waktunya bagi proses penyusunan Laporan Pertang-gungjawaban Keuangan Kepala Daerah kepada masyarakat melalui Dewan Perwakilan Rakyat Daerah. .

\section{TINJAUAN PUSTAKA}

Hubungan keagenan dalam teori agensi muncul ketika ada penugasan dari individu (prinsipal) kepada individu lain (agen). Menurut Jensen \& Meckling (1976) masalah keagenan dapat muncul karena setiap individu diasumsikan akan mempunyai preferensi untuk memaksimalkan utilitas pribadi yang kemungkinan besar berlawanan dengan kepentingan individu lain. Berdasarkan asumsi ini kemungkinan akan terjadi kegagalan oleh agen dalam melaksanakan tugas dikarenakan agen lebih memilih untuk memaksimalkan kepentingan pribadi.

Mengacu pada Undang-Undang Nomor 32 tahun 2004 partisipan 
pada organisasi pemerintahan meliputi rakyat, bupati atau walikota, dan DPRD. Dalam undang-undang tersebut, bupati dan walikota mempunyai tanggung jawab atas perencanaan, pelaksanaan dan pertanggungjawaban program pemerintah sehingga berperan sebagai eksekutif. Mekanisme pemilihan bupati dan walikota oleh rakyat menunjukkan adanya pelimpahan wewenang dari rakyat kepada bupati dan walikota. Hal ini menunjukkan bahwa Bupati dan Walikota berperan sebagai agen dan rakyat merupakan prinsipal dalam rerangka hubungan keagenan. Dalam UU Nomor 32 tahun 2004 DPRD merupakan mitra kerja bupati dan walikota yang berperan dalam fungsi pengawasan dan legislasi.

Sesuai dengan Standar Akuntansi Pemerintahan (SPAP) No. 1, dalam rangka untuk memenuhi tujuan umum atas laporan keuangan daerah, maka dalam penyajian laporan keuangan harus menyediakan informasi mengenai entitas pelaporan yang terdiri dari: Laporan Realisasi Anggaran (LRA), Neraca, Laporan Arus Kas, dan Catatan atas Laporan Keuangan.

Memesah (1995:16) mengemukakan bahwa keuangan daerah secara sederhana dapat dirumuskan sebagai semua hak dan kewajiban yang dapat dinilai dengan uang, demikian pula segala sesuatu baik berupa uang maupun barang yang dapat dijadikan kekayaan daerah sepanjang belum dimiliki/dikuasai oleh negara atau daerah yang lebih tinggi serta pihak-pihak lain sesuai dengan ketentuan perundangundangan yang berlaku. Yuwono dkk. (2008:42) mengatakan bahwa keuangan daerah adalah semua hak dan kewajiban daerah dalam rangka penyelenggaraan pemerintah daerah yang dapat dinilai dengan uang, termasuk segala bentuk kekayaan yang berhubungan dengan hak dan kewajiban daerah.

Peraturan pemerintah No. 58 tahun 2005 disebutkan bahwa 
keuangan daerah dikelola secara tertib, taat pada peraturan perundangundangan, efisien, ekonomis, efektif, transparan, dan bertanggung jawab dengan memperhatikan asas keadilan, kepatuhan, dan manfaat untuk masyarakat. Pengelolaan keuangan daerah dilaksanakan dalam suatu sistem yang terintegrasi dan diwujudkan dalam APBD yang setiap tahun ditetapkan dengan peraturan daerah.

Pertanggungjawaban dapat diartikan secara sempit maupun secara luas mengemukakan bahwa pertanggungjawaban keuangan dalam arti sempit yaitu pertanggungjawaban keuangan (disebut SPJ) yang disampaikan Bendaharawan setiap bulannya kepada Daerah dalam hal ini kepada kepala Biro/Bagian Keuangan selambat-lambatnya tanggal 10 bulan berikutnya, sedang pengertian secara luas yaitu pertanggungjawaban keuangan oleh Pemerintah (eksekutif) kepada rakyat melalui wakil-wakilnya di DPRD serta kepada Pemerintah atau Pemerintah yang lebih tinggi, pengertian surat tersebut di atas sebatas dalam konteks pertanggungjawaban keuangan Pemerintah Daerah (Mamesah 1995:155).

Dalam Permendari No. 55 Tahun 2008 membedkan bendahara menjadi 2 bagian yaitu:

a. Bendahara Penerimaan adalah pejabat fungsional yang ditunjuk untuk menerima, menyimpan, menyetorkan, menatausahakan, dan mempertanggungjawabkan uang pendapatan asli daerah dalam rangka pelaksanaan APBD pada SKPD.

b. Bendahara Pengeluaran adalah pejabat fungsional yang ditunjuk menerima, menyimpan, membayarkan, menata-usahakan, dan mempertanggungjawabkan uang untuk keperluan belanja daerah dalam rangka pelaksanaan APBD pada SKPD.

Dalam pengajuan laporan, khususnya laporan pertanggungjawaban keuangan ini pengadministrasiannya diatur berdasarkan suatu 
ketentuan perundang-undangan yang diatur Peraturan Menteri Dalam Negeri No. 55 tahun 2008 tentang pertanggungjawaban tata administrasif.

\section{Kerangka Berpikir}

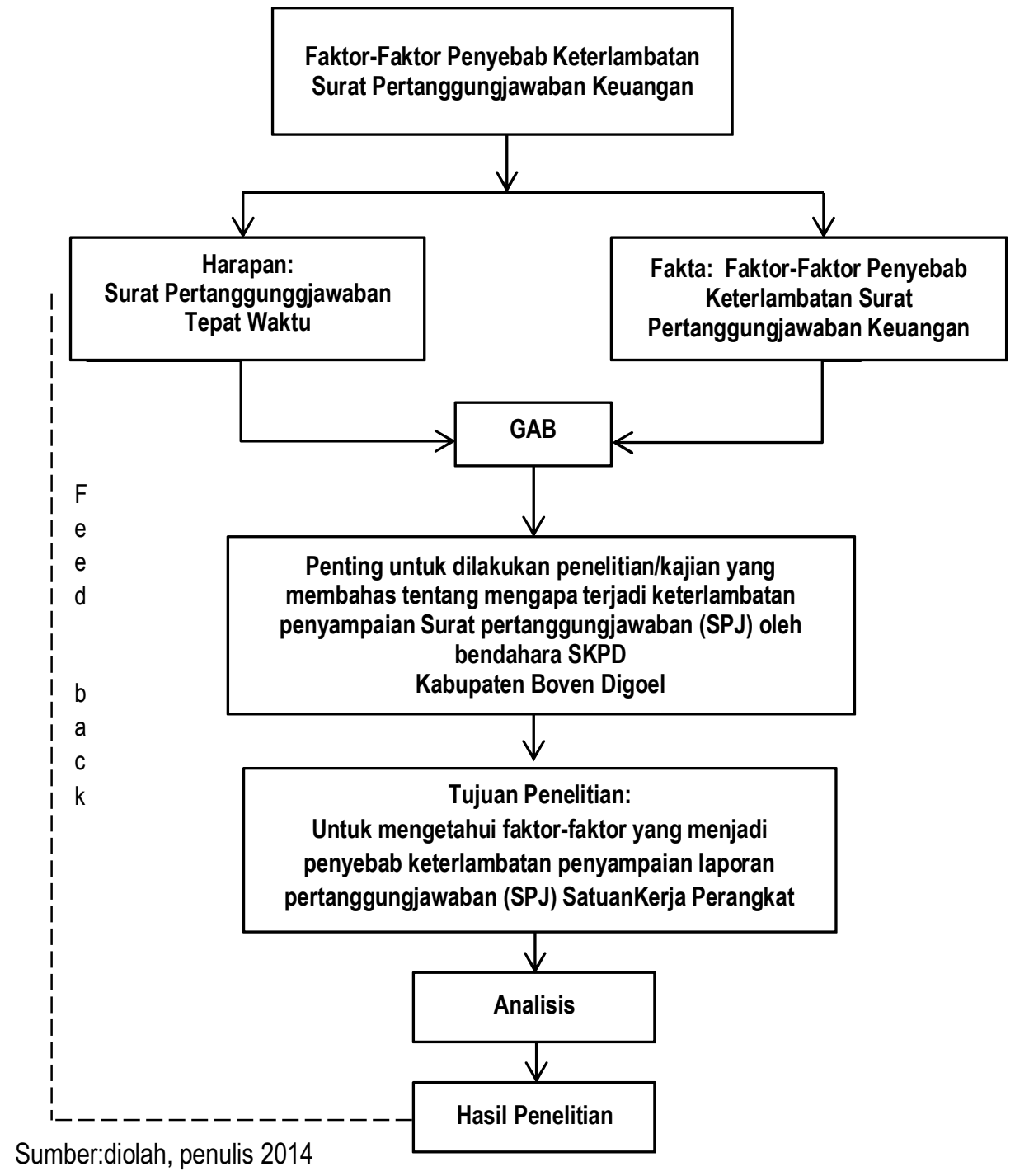

\section{Hipotesis Penelitian}

a. (H1) Diduga bahwa aspek sumberdaya manusia (SDM) berpengaruh terhadap keterlambatan surat pertanggungjawaban (SPJ). 
b. $(\mathrm{H} 2)$ Diduga bahwa aspek teknis (perencanaan APBD) berpengaruh terhadap keterlambatan surat pertanggungjawaban (SPJ).

c. (H3) Diduga bahwa aspek teknis (rekanan yang terlambat) berpengaruh dalam penyusunan surat pertanggungjawaban (SPJ).

\section{METODE PENELITIAN}

\section{Populasi dan Sampel}

Pendekatan dalam penelitian ini termasuk dalam penelitian kuantitatif. Dalam penelitian ini dilakukan pengujian jalur empiris dan pengukuran berdasarkan teori yang ada. Model penelitian ini adalah model penelitian survei dengan menggunakan instrument kuesioner.

Dalam penelitian ini yang menjadi populasi adalah SKPD dipemerintah Kabupaten Boven Digoel yaitu sebanyak 19 SKPD. Desain pengambilan sampel dalam penelitian ini adalah dengan metode nonprobabilitas, teknik sampling menggunakan teknik pengambilan sampel bertujuan (purposive sampling), yang terdiri dari:

a. Pegawai SKPD yang terlibat dalam pertanggungjawaban keuangan

b. Bendahara SKPD

Pengambilan sampel dalam hal ini terbatas pada orang tertentu yang dapat memberikan informasi yang diinginkan yaitu bendahara yang terkait dengan pertanggungjawaban keuangan Kabupaten Boven Digoel sebanyak 97 Responden.

\section{Definisi Operasional dan Pengukuran Variabel}

Terdapat 3 variabel yang diteliti yaitu aspek Sumberdaya Manusia (SDM), Perencanaan APBD dan Rekanan yang terlambat. 
Kuesioner aspek SDM dimodifikasi dari Anzar (2007). Variabel ini diukur melalui 3 indikator yaitu pendidikan, pelatihan dan pengalaman. Indikator ini terwakili melalui 5 pernyataan. Kuesioner Aspek Perencanaan APBD dimodifikasi dari Indrijawati (2010). Variabel ini diukur melalui 3 indikator yaitu disiplin anggaran, pelaksanaan anggaran yang terarah. Indikator ini terwakili melalui 4 pernyataan. Sedangkan kuesioner aspek rekanan yang terlambat dimodifikasi dari Nilawati (2009). Variabel ini diukur melalui 2 indikator yaitu ketidaksesuaian Dik/Dip dan keterbatasan anggaran. Indikator ini terwakili melalui 3 pernyataan. Skala likert yang digunakan dalam mengukur ketiga aspek diatas dimulai dari sangat tidak setuju dengan skor 1 sampai dengan sangat setuju dengan skor 5.

\section{Jenis dan Sumber Data}

Data primer secara khusus dikumpulkan oleh peneliti untuk menjawab pertanyaan penelitian berdasarkan kuesioner yang diedarkan kepada responden. Dalam penelitian ini data sekunder diperoleh dari SKPD Kabupaten Boven Digoel, jurnal, laporanlaporan, dokumen-dokumen, buku-buku dan literatur-literatur lain yang membahas mengenai materi penelitian dan data pendukung lainnya yang dianggap dapat mendukung penelitian ini.

\section{Teknik Pengumpulan Data}

Pengumpulan data primer dilakukan dengan metode penelitian lapangan (field research) dengan teknik pengumpulan data sebagai berikut:

1. Penyebaran dan pengisian kuesioner, sistim penyampaian kuesioner atau daftar pertanyaan terstruktur dilakukan secara langsung (tidak melalui pos atau e-mail). 
2. Kuesioner yang disampaikan kepada responden berisikan pertanyaan tertutup.

3. Kuesioner diisi sendiri oleh responden, dan akan dikumpulkan pada saat itu juga.

\section{Uji Kualitas Instrument}

Pengujian kualitas instrument penelitian dilakukan melalui uji validitas dan reliabilitas dalam penelitian ini.

\section{Uji Asumsi Klasik}

Menurut Sekaran (2006), untuk dapat melakukan analisis regresi berganda, maka perlu dilakukan pengujian terhadap asumsi analisis, yaitu: normalitas, multikolinieritas, dan heteroskedastisitas. Agar data yang terkumpul dapat bermakna dan bermanfaat sehingga menghasilkan BLUE (Best Linear Unbiased Estimator).

\section{Analisa Data}

Untuk menguji hipotesis penelitian ini menggunakan Analisis regresi linier berganda (Regression Multiple Analysis).Variabel independent dalam penelitian ini yaitu: Aspek SDM, aspek perencanaan APBD dan aspek rekanan yang terlambat. Sedangkan variabel dependent yaitu keterlambatan surat pertanggungjawaban (SPJ). Dengan persamaan sebagai berikut:

$$
\mathbf{Y}=\mathbf{a}+\boldsymbol{\beta}_{1} \mathbf{X}_{1}+\boldsymbol{\beta}_{2} \mathbf{X}_{2}+\boldsymbol{\beta}_{3} \mathbf{X}_{3}+\mathbf{e}
$$

Keterangan:

$Y$ : Keterlambatan Surat Pertanggungjawaban (SPJ)

$\mathrm{X} 1$ : Aspek SDM

X2 : Aspek Perencanaan APBD

X3 : Aspek Rekanan yang terlambat

$\beta$ : Koefisien Regresi

a : Konstanta

e : Error 


\section{Pengujian Hipotesis}

Pengujian hipotesis untuk penelitian ini menggunakan analisis regresi dengan menggunakan Software SPSS Statistics versi 21 dilakukan dengan melakukan Uji Koefisien Determinasi (R), Uji Signifikansi Simultan (Uji Statistik F), dan Uji Signifikansi Parameter Individual (Uji Statistik t) (Ghozali, 2005).

\section{HASIL DAN PEMBAHASAN}

\section{Karakteristik Repsonden}

Dari kuesioner yang disebarkan ke 162 responden yang berada pada SKPD di Kabupaten Boven Digoel, kuesioner yang kembali berjumlah 135 yang terdiri dari 11 Dinas, 6 Badan dan 2 Kantor serta 17 Distrik. Kuesioner yang tidak kembali sebanyak 35 sedangkan 13 kuesioner tidak lengkap sehingga tidak dimasukan dan digunakan. Total kuesioner yang dapat diolah sebesar 97 responden atau 71 . $85 \%$ yang kemudian dianalisis. Mayoritas responden bendahara berjenis kelamin perempuan yaitu sebanyak 79 orang atau $81.44 \%$ sedang responden berjenis kelamin laki-laki sebanyak 18 orang atau $18.56 \%$.

Hasil uji validitas dan realibilitas keseluruhan instrument menunjukan bahwa hasil uji kolerasi untuk item memiliki nilai koefisien alpha cronbach's diatas 0,60 (Tabel 4.1) sehingga variabel pada tiap item pertanyaan dikatakan valid dan reliabel untuk dapat digunakan dalam pengolahan data selanjutnya. 
Tabel 1

Pengujian Instrumen Penelitian

(Uji Validitas \& Reliabilitas)

\begin{tabular}{|c|c|c|c|c|c|}
\hline Variabel & Item & Korelasi & Ket & $\begin{array}{c}\text { Alpha } \\
\text { Cronbach }\end{array}$ & Ket \\
\hline \multirow{5}{*}{ Aspek SDM $\left(\mathrm{X}_{1}\right)$} & $\mathrm{X} 1.1$ & 0.875 & $\begin{array}{l}\text { Valid } \\
\end{array}$ & \multirow{5}{*}{0.922} & \multirow{5}{*}{ Realibel } \\
\hline & $\mathrm{X} 1.2$ & 0.850 & Valid & & \\
\hline & X1.3 & 0.794 & $\begin{array}{l}\text { Valid } \\
\end{array}$ & & \\
\hline & $\mathrm{X} 1.4$ & 0.774 & Valid & & \\
\hline & $\begin{array}{l}\mathrm{X} 1.5 \\
\end{array}$ & 0.704 & $\begin{array}{c}\text { Valid } \\
\end{array}$ & & \\
\hline \multirow{4}{*}{$\begin{array}{c}\text { Aspek } \\
\text { perencanaan } \\
\text { APBD }\left(\mathrm{X}_{2}\right)\end{array}$} & X2.1 & 0.644 & $\begin{array}{c}\text { Valid } \\
\end{array}$ & \multirow{4}{*}{0.829} & \multirow{4}{*}{ Realibel } \\
\hline & $\mathrm{X} 2.2$ & 0.668 & Valid & & \\
\hline & $\mathrm{X} 2.3$ & 0.640 & Valid & & \\
\hline & $\mathrm{X} 2.4$ & 0.678 & $\begin{array}{l}\text { Valid } \\
\end{array}$ & & \\
\hline \multirow{3}{*}{$\begin{array}{c}\text { Aspek rekanan } \\
\text { yang terlambat } \\
\left(\mathrm{X}_{3}\right)\end{array}$} & X3.1 & 0.897 & $\begin{array}{c}\text { Valid } \\
\end{array}$ & \multirow{3}{*}{0.953} & \multirow{3}{*}{ Realibel } \\
\hline & X3.2 & 0.900 & $\begin{array}{c}\text { Valid } \\
\end{array}$ & & \\
\hline & X3.3 & 0.912 & Valid & & \\
\hline \multirow{3}{*}{$\begin{array}{l}\text { Keterlambatan } \\
\text { SPJ (Y) }\end{array}$} & Y1.1 & 0.808 & Valid & \multirow{3}{*}{0.917} & \multirow{3}{*}{ Realibel } \\
\hline & $\begin{array}{l}\mathrm{Y} 1.2 \\
\end{array}$ & 0.865 & Valid & & \\
\hline & Y1.3 & 0.876 & Valid & & \\
\hline
\end{tabular}

Sumber; Data diolah, (2014)

\section{Analisa}

Hasil pengujian dengan menggunakan analisis regresi berganda dengan menggunakan SPSS seperti yang terlihat pada Tabel 2 dibawah ini.

Tabel 2.

Hasil Analisis Regresi

\begin{tabular}{|c|c|c|c|c|}
\hline Variabel & $\begin{array}{c}\text { Standardized } \\
\text { Coefficients }\end{array}$ & thitung & Sig & Keterangan \\
\hline Constant & 2.056 & & & \\
\hline Aspek SDM & 0.399 & 9.942 & 0.000 & Signifikan \\
\hline Aspek Perencanaan APBD & 0.162 & 2.973 & 0.000 & Signifikan \\
\hline $\begin{array}{l}\text { Aspek Rekanan Yang } \\
\text { Terlambat }\end{array}$ & -0.013 & -463 & 0.645 & $\begin{array}{c}\text { Tidak } \\
\text { berpengaruh }\end{array}$ \\
\hline R Square & \multicolumn{4}{|c|}{0.871} \\
\hline Ajusted R Square & \multicolumn{4}{|c|}{0.866} \\
\hline t tabel & \multicolumn{4}{|c|}{1.660} \\
\hline
\end{tabular}

Sumber : data diolah, (2014) 
Dari data diatas menunjukan bahwa persamaan regresi dalam penelitian ini adalah sebagai berikut:

$$
Y=2.056+0.399+0.162-0.13+e
$$

Koefisien determinasi (R2) pada intinya mengukur seberapa jauh kemampuan model dalam menerangkan variabel dependen. Nilai yang digunakan adalah adjusted R2 karena variabel independen yang digunakan dalam penelitian ini lebih dari dua variabel. Adapun nilai adjusted R2 dari hasil perhitungan terlihat pada tabel 3 .

Tabel 3.

Nilai Koefisien Determinasi R2

\begin{tabular}{|c|r|r|r|r|r|}
\hline \multicolumn{7}{|c|}{ Model Summary } \\
\hline Model & $\mathrm{R}$ & $\mathrm{R}$ Square & $\begin{array}{c}\text { Adjusted R } \\
\text { Square }\end{array}$ & $\begin{array}{c}\text { Std. Error of the } \\
\text { Estimate }\end{array}$ & Durbin-Watson \\
\hline 1 & $.933^{\mathrm{a}}$ & .871 & .866 & .8186 & 1.872 \\
\hline
\end{tabular}

a. Predictors: (Constant), Aspek Rekanan Yang Terlambat, Aspek SDM, Aspek Perencanaan APBD

b. Dependent Variable: Keterlambatan SPJ

Sumber : data diolah, (2014)

Dari tabel 3 diatas menunjukan besarnya pengaruh aspek rekanan SDM (X1), Aspek perencanaan APBD (X2) dan Aspek rekanan yang terlambat $(X 3)$ sebagai variabel independen terhadap variabel dependen keterlambatan SPJ (Y) yang dapat diterangkan oleh model persamaan ini adalah sebesar $86,6 \%$ dan sisanya sebesar $13,4 \%$ dipengaruhi oleh faktor-faktor lain yang tidak dimasukkan dalam model regresi.

Berdasarkan hasil analisis regresi dapat diketahui bahwa variabel independen aspek rekanan SDM (X1), Aspek perencanaan APBD (X2) dan Aspek rekanan yang terlambat (X3) secara bersama-sama berpengaruh signifikan terhadap keterlambatan SPJ (Y). Hal ini dapat dibuktikan dari nilai $\mathrm{F}$ sebesar 208,657 yang lebih besar dari tingkat 
signifikasinya yakni nilai probalitas alfa $(\alpha)=0.005)$ seperti ditunjukkan pada tabel 4.4 sebagai berikut.

Tabel 4.

Uji F

\begin{tabular}{|l|r|r|r|r|c|c|}
\hline \multicolumn{7}{|c|}{ ANOVA $^{\text {a }}$} \\
\hline \multicolumn{2}{|c|}{ Model } & $\begin{array}{c}\text { Sum of } \\
\text { Squares }\end{array}$ & Df & Mean Square & F & Sig. \\
\hline \multirow{3}{*}{1} & Regression & 419.437 & 3 & 139.812 & 208.657 & $.000^{\mathrm{b}}$ \\
\cline { 2 - 7 } & Residual & 62.315 & 93 & .670 & & \\
\cline { 2 - 7 } & Total & 481.753 & 96 & & & \\
\hline \multicolumn{2}{|l}{ a. Dependent Variable: Keterlambatan SPJ } \\
$\begin{array}{l}\text { b. Predictors: (Constant), Aspek Rekanan Yang Terlambat, Aspek SDM, Aspek } \\
\text { Perencanaan APBD }\end{array}$ \\
\hline
\end{tabular}

Sumber : data diolah, (2014)

Pengujian parsial dilakukan dengan membandingkan nilai signifikansi $t$ yang ditunjukkan oleh Sig dari t pada Tabel 4 dengan tingkat signifikansi yang diambil, dalam hal ini 0,05. Jika nilai Sig dari $t<0,05$ maka variabel independen berpengaruh terhadap variabel dependen.

Tabel 5.

Coefficientsa

Uji t

\begin{tabular}{|c|c|c|c|c|c|c|c|}
\hline \multirow[t]{2}{*}{ Model } & \multicolumn{2}{|c|}{$\begin{array}{l}\text { Unstandardized } \\
\text { Coefficients }\end{array}$} & \multirow{2}{*}{$\begin{array}{c}\begin{array}{c}\text { Standardized } \\
\text { Coefficients }\end{array} \\
\text { Beta }\end{array}$} & \multirow[t]{2}{*}{ t } & \multirow[t]{2}{*}{ Sig. } & \multicolumn{2}{|c|}{$\begin{array}{l}\text { Collinearity } \\
\text { Statistics }\end{array}$} \\
\hline & $B$ & $\begin{array}{l}\text { Std. } \\
\text { Error }\end{array}$ & & & & Tolerance & VIF \\
\hline (Constant) & 2.056 & .543 & & 3.787 & .000 & & \\
\hline Aspek SDM & .399 & .040 & .737 & 9.942 & .000 & .253 & 3.954 \\
\hline $\begin{array}{ll} & \text { Aspek } \\
1 & \text { Perencanaan } \\
& \text { APBD }\end{array}$ & .162 & .054 & .221 & 2.973 & .004 & .253 & 3.957 \\
\hline $\begin{array}{l}\text { Aspek Rekanan } \\
\text { Yang Terlambat }\end{array}$ & -.013 & .028 & -.017 & -.463 & .645 & .992 & 1.008 \\
\hline
\end{tabular}

Sumber : data diolah, (2014)

Pada persamaan tersebut menunjukan angka yang signifikan pada variabel aspek SDM (X1), aspek perencanaan APBD (X2). Dan aspek rekanan yang terlambat $(\mathrm{X} 3)$. 


\section{Pengujian Hipotesis Penelitian}

Adapun pengujian hipotesis dalam kajian ini dilakukan dengan asumsi sebagai berikut; $\mathrm{H}_{\mathrm{a}}$ diterima jika $\mathrm{t}$ hitung $>t$ tabel, dengan kata lain ada pengaruh variabel independen terhadap keterlambatan SPJ dan $\mathrm{H}_{0}$ diterima jika $\mathrm{t}$ hitung $<\mathrm{t}$ tabel, dengan kata lain variabel independen tidak mempengaruhi keterlambatan SPJ.

Berdasarkan hasil analisis ditemukan bahwa variabel aspek SDM terbukti berpengaruh secara signifikan dan positif terhadap keterlambatan SPJ. Hal ini ditunjukan dengan besarnya nilai thitung sebesar 9.942 sedangkan $t_{\text {tabel }} 1.660$ sehingga $t_{\text {hitung }}>t_{\text {tabel }}(9.942>$ 1.660) dengan nilai koefisien regresi adalah sebesar 0.399. Hasil pengujian ini menunjukan bahwa hipotesis penelitian pertama diterima.

Berdasarkan hasil analisis ditemukan bahwa aspek perencanaan APBD berpengaruh secara signifikan dan positif terhadap keterlambatan SPJ. Hal ini ditunjukan dengan besarnya nilai $t_{\text {hitung }}$ sebesar 2.973 sedangkan $t_{\text {tabel }} 1.660$ sehingga $t_{\text {hitung }}>t_{\text {tabel }}$ $(2.973>1.660)$ dengan nilai koefisien regresi adalah sebesar 0.162 . Hasil pengujian ini menunjukan bahwa hipotesis penelitian kedua diterima.

Berdasarkan hasil analisis ditemukan bahwa aspek rekanan yang terlambat tidak berpengaruh secara terhadap keterlambatan SPJ. Hal ini ditunjukan dengan besarnya nilai $t_{\text {hitung }}$ sebesar -0.463 sedangkan $t_{\text {tabel }} 1.660$ sehingga $t_{\text {hitung }}>t_{\text {tabel }}(-0.463<1.660)$ dengan nilai koefisien regresi adalah sebesar -0.013 . Hasil pengujian ini menunjukan bahwa hipotesis penelitian ketiga ditolak.

Hasil analisis menunjukan bahwa seluruh variabel independen yang terdiri dari; aspek SDM, aspek perencanaan APBD dan aspek rekanan yang terlambat terbukti mempengaruhi keterlambatan surat 
pertanggungjawaban keuangan di Kabupaten Boven Digoel terbukti berpengaruh secara positif dan signifikan terhadap keterlambatan surat pertanggungjawabab keuangan artinya bahwa dua hipotesis penelitian yang diuji diterima yaitu aspek SDM dan aspek perencanaan APBD, sedangkan aspek rekanan yang terlambat terbukti tidak berpengaruh terhadap keterlambatan surat pertanggungjawaban keuangan.

Dari hasil pengujian hipotesis diatas terbukti aspek SDM berpengaruh secara positif dan signifikan terhadap keterlambatan surat pertanggungjawaban. Hal ini dapat dinterprestasikan bahwa rendahnya kualitas SDM, hal yang menjadi titik lemah atas surat pertanggungjawaban di SKPD adalah realita yang terjadi pada kabupaten Boven Digoel penunjukkan bendahara hanya didasarkan pada loyalitas kepada atasan semata tanpa memperhatikan spesifikasi kemampuan yang dimiliki dan persyaratan khusus seperti harus mengikuti kursus atau pelatihan terkait perbendaharaan terlebih dahulu, hal ini dapat mengakibatkan kualitas bendahara di SKPD Kabupaten Boven Digoel mengalami keterlambatan dalam menyampaikan surat pertanggungjawaban (SPJ) yang diakibatkan karena rendahnya SDM yang dimiliki SKPD.

Keterlambatan penyampaian surat pertanggungjawaban juga disebabkan karena masih terdapatnya beberapa kesalahan dalam penyampaian pertanggungjawaban atas laporan kegiatan dari PPTK kepada bendahara disebabkan karena sebagai petugas teknis, PPTK kurang menguasai ketentuan administrasi keuangan.

Disisi lain PPK-SKPD tidak mampunya PPK-SKPD dalam melakukan tugasnya disebabkan karena kebijakan penunjukkan PPKSKPD yang hanya

berdasarkan pertimbangan jabatan struktural (Sekretaris SKPD/Kasubbag Keuangan) sementara hanya sedikit dari mereka yang 
memiliki latar belakang tugas sebagai bendahara dan juga berlatar belakang pendidikan ekonomi/akuntansi.

Hasil pengujian hipotesis kedua terbukti aspek perencanaan APBD berpengaruh positif dan signifikan terhadap keterlambatan SPJ hal ini dapat dijustifikasi bahwa perencanaan yang kurang baik akan mengganggu menghambat proses perencanaan secara keseluruhan, dimana secara otomatis akan menghambat arah dan kebijakan yang akan diambil pemerintah daerah dalam melaksanakan rencana kerja pemerinatah daerah (RKPD) yang telah ditentukan baik melalui RPJMD maupun RPJP dan hal ini juga akan membawa dapak terhadap surat pertanggung jawaban akan mengalami keterlambatan.

Hasil penelitian diatas terbukti bahwa aspek rekanan yang terlambat tidak memberikan dampak yang signifikan terhadap keterlambatan SPJ. Rekanan yang terlambat belum memberikan umpan balik yang substansial untuk mencegah terjadinya penyimpangan keterlambatan surat pertanggungjawaban. Akibat keterbatasan SDM yang belum profesional dan perencanaan APBD yang belum tersusun secara optimal dalam menjalankan pengawasan terhadap pertanggungjawaban keuangan yang dilakukan sehingga keterlambatan pertanggungjawaban keuangan yang dilakukan oleh rekanan yang terlambat menyampaikan bukti kurang memberikan dampak atas pertanggungjawaban keuangan.

\section{KESIMPULAN DAN SARAN}

\section{Kesimpulan}

Berdasarkan pembahasan hasil penelitian maka kesimpulan penelitian yang dapat disampaikan antara lain;

a. Aspek sumber daya manusia (SDM) terbukti berpengaruh secara positif terhadap keterlambatan surat pertanggungjawaban (SPJ) pada Kebupaten Boven Digoel. Hal ini berarti bahwa jika sumber 
daya manusia meningkat atau semakin baik maka tingkat keterlambatan surat pertanggungjawaban keuangan pada Kebupaten Boven Digoel juga akan semakin baik atau dapat dikatakan dorongan peningkatan sumberdaya manusia akan mengurangi keterlambatan surat pertanggungjawaban (SPJ) pada Kebupaten Boven Digoel

b. Aspek perencanaan APBD terbukti berpengaruh secara positif dan signifikan terhadap keterlambatan surat pertanggungjawaban (SPJ) pada Kebupaten Boven Digoel. Hal ini berarti bahwa jika aspek perencanaan APBD meningkat atau semakin baik maka tingkat keterlambatan surat pertanggungjawaban (SPJ) pada Kebupaten Boven Digoel juga akan semakin menurun atau bahwa dorongan peningkatan perencanaan APBD akan meningkatkan pula dan mampu mengatasi keterlambatan surat pertanggungjawaban (SPJ) pada Kebupaten Boven Digoel

c. Aspek rekanan yang terlambat terbukti tidak memberikan dampak yang signifikan terhadap keterlambatan surat pertanggungjawaban keuangan pada Kebupaten Boven Digoel. Rekanan yang terlambat belum memberikan umpan balik yang substansial untuk mencegah terjadinya penyimpangan keterlambatan surat pertanggungjawaban keuangan.

\section{Saran}

Saran yang dapat disampaikan berdasarkan hasil penelitian ini adalah;

a. Perlunya adanya perhatian yang lebih baik dari Pemerintah Kabupaten Boven Digoel menyangkut aspek sumber daya manusia (SDM), kerena kemampuan SDM merupakan salah salu factor yang sangat penting dalam pelaksanaan otonomi daerah, khususnya terkait keterlambatan SPJ pemerintah daerah di 
Kabupaten Boven Digoel, sehingga keterlambatan SPJ diharapkan tidak terjadi lagi karena hal ini didukung oleh SDM manusia yang mampu melaksanakan tugas dan fungsi dengan baik.

b. Perlunya adanya perhatian yang lebih baik dari Pemerintah Kabupaten Boven Digoel menyangkut aspek perencanaan APBD, hal ini perlu menjadi perhatian khusus pemerintah daerah Kabupaten Boven Digoel karena tanpa perencanaan APBD yang baik maka akan menghambat pada semua proses kegiatan pemerintah daerah kabupaten Boven Digoel sehingga dengan sendirinya akan berdampak pada keterlambatan SPJ pemerintah Kabupaten Boven Digoel.

c. Pihak ketiga yang melakukan belanja langsung dari setiap SKPD berkaitan dengan perencanaan pertanggungjawaban berpedoman pada DPA dan APBD yang telah disusun sering mengalami keterlambatan pelaporan yang terjadi karenatidak sesuai dengan realita pelaksanaan di lapangan yang diantaran:

a) SKPD belum mampu melaksanakan tugas dengan baik sesuai dengan tupoksi yang telah ditetapkan.

b) SKPD belum mampu melaksanakan pertanggungjawaban dengan baik dalam menyelesaikan pertanggungjawaban keuangan.

c) SKPD belum taat terhadap peraturan perundangundangan yang berlaku.

\section{DAFTAR PUSTAKA}

Anthoni Robert N dan Hermanson Roger H. 1990. Akuntansi Manajemen, Program Belajar Mandiri, Rineka Cipta, Jakarta.

Arikunto, S. 2002. Prosedur Penelitian Suatu Pendekatan Praktek. Cetakan Ke dua belas, edisi revisi V. Jakarta : Rineka Cipta 
Azhar, 2007. Faktor-faktor yang mempengaruhi Keberhasilan Penerapan Permendagri No.13 pada Pemerintah Kota Banda Aceh.Tesis. Program Pasca Sari ana USU : Medan.

Bastian, Indra. 2001. Akuntansi Sektor Publik di Indonesia, Penerbit : BPFE Yoyakarta.

Choirunisah, 2008. Faktor-faktor yang mempengaruhi kualitas informasi laporan keuangan yang di hasilkan oleh system akuntansi instansi (studi Kasus KPPN Malang). Tesis Progam Pascasarjana Fakultas Ekonomi Universitas Brawijaya Malang.

Dadang Solihin, Putut Maryati. 2002. PanduanLengkap Otonomi Daerah, ISMEE. Jakarta.

Ghozali, Imam. 2005. Aplikasi Analisis Mulivariate dengan Program SPSS, Edisi 3, Badan Penerbit Universitas Diponegoro, Semarang.

Jones, Rowan and Maurice Pendlebury. 2000. Public Sector Accounting, 5 th Ed, London: Pitman Publishing

Halim, Abdul. 2004. Akutansi Sektor Publik (Akuntansi Keuangan Daerah), edisi revisi, Salemba Empat.

Hartono, Jogiyanto. 2008. Metodologi Penelitian Bisnis, Salah Kaprah dan Pengalaman-Pengalaman. BPFE Univ. Gadjah Mada, Edisi 2007, Cetakan Pertama, Yogyakarta.

Jurnal Akuntansi dan Auditing Indonesia (JAAI) Vol 4 No 1 Mardiasmo. 2002. Akuntansi Sehor Publik, Penerbit Andi. Yogyakarta.

Mardiasmo. 2000. Reformasi Pengelolaan Keuangan daerah, Implemetasi value formoney audit sebagai antisipasi terhadap tuntutan akuntabilitas public.

Pedoman Penyusunan Pelaporan Akuntabilitas Kinerja Instansi Pemerintah, 1999, Lembaga Administrasi Negara Republik Indonesia, Jakarta.

Pemerintah Republik Indonesia. 1998. Ketetapan MPR Nomor IX Tahun 1998, Tentang Penyelenggaran Negara Yang Bersih dan Bebas Koropsi, Kolusi dan Nepotisme.

1999a. Undang-Undang RI No. 22 Tahun 1999. tentang Pemerintah Daerah. 
1999b. Undang-Undang RI No. 25

Tahun 1999. tentang Perimbangan Keuangan antara Pemerintah Pusat dan Daerah.

105 Tahun 2000 Tentang Pengelolaan dan

Pertanggungjawaban Keuangan Daerah.

105 Tahun 2000 tentang Pengelolaan Dan

Pertanggungjawaban Keuangan Daerah.

2002. Keputusan Menteri Dalam Negeri

Nomor 29 Tahun 2002 Tentang Pedoman Pengurusan, Pertanggungjawaban dan Pengawasan Keuangan Daerah, Departemen Dalam Negeri, Jakarta.

2003. Undang-undang RI Nomor 17 tahun 2003, tentang Keuangan Negara.

2004a. Undang-Undang Nomor 32 Tahun 2004 Tentang Pemerintahan Daerah. Direktorat Jenderal Otonomi Daerah, Jakarta.

2004b. Undang-Undang Nomor 33 Tahun 2004 tentang Perimbangan Keuangan Antara Pemerintah Pusat Dan Pemerintahan Daerah. Direktorat Jenderal Otonomi Daerah, Jakarta.

2004c. Peraturan Pemeintah No. 21 tahun 2004 tentang Rencana Kerja dan Anggaran Kementrian Negara/Lembaga.

2004d. Peraturan Pemerintah No. 20 tahun 2004 tentang Rencana Kerja Pemerintah.

2004e. Peraturan Pemerintah No. 24 tahun 2004 tentang Standar Akuntansi Pemerintahan (SAP).

2004f. Undang-undang RI No. 1 tahun 2004 tentang Perbendaharaan Negara.

2004g. Undang-undang RI No. 15 tahun 2004 tentang Pemeriksanaan Pengelolaan dan Tanggung Jawab Keuangan Negara.

2005a. Peraturan Pemerintah Nomor 58 Tahun 2005 Tentang Pengelolaan Keuangan Daerah. 
2005b. Peraturan Pemerintah No 58 tahun 2005 tentang Pengelolaan Keuangan Daerah.

2008. Nomor 55 Tahun 2008 tentang Tata Cara Penatausahaan dan Pelaporan Pertanggungjawaban Bendahara.

Ruchiyat, Kosasih. 1991. pentingnya pengukuran Prestasi BUMN untukpenyehatan dan penyempurnaan pengelolaan " majalah Akuntansi No 2, Pebruari, Jakarta: PT. Gramedia.

Sistem Akuntabilitas Kinerja Instansi Pemerintah (AKIP), 1999, Lembaga Administrasi Negara \& Badan Pemeriksa Keuangan dan Pembangunan, Jakarta.

Santoso, S. 2000. SPSS Mengolah Data Statistik Secara Profesional. Cetakan Kedua. Elex Media Computindo, Jakarta.

Smith Garry D, Arnold, Denny R, Bizzel Boby G. 1992. Business Strategy and Policy:; Third Edition, Boston Houghton Mifflin Company.

Suad Husnan dan Enny Pudjiastuti. 1994. Dasar- Dasar Manajemen Keuangan, "Edisi Pertama, UPP AMP YKPM Yogyakarta.

Sugiyono. 2003. Metode Penelitian Kuantitatif, Kualitatif, dan R\&D. Penerbit Alfabeta. Bandung

Supriyono, R.A. 1990. Manajemen Strategi dan Kebijakan Bisnis", Edisi Pertama Yogyakarta BPFE.

Sarwoto. 1991. Dasar-Dasar Organisasi dan Manajemen, Ghalia Indonesia, Jakarta.

Singarimbun M dan Effendi S. 1987. Metode Penelitian Survei, LP3ES, Yogyakarta

Sugiyono. 2003. Statistika Untuk Penelitian, CV. Alfabeta, Bandung

Swasto Bambang. 2003. Pengembangan Sumber Daya Manusia (Pengaruhnya terhadap kinerja dan imbalan), Bayumedia, Malang.

Thompson, Arthur A Striekland JA. 1995. " Stratgic Management Concepts and Cases, "Fifth edition, Boston BPI, Irwin. 
Tjiptono Fandi dan Diana Anastasia. 2001. Total Quality Management (TQM), Edisi Revisi, Andi, Yogyakarta.

Tuasikal, A. 2007. Pengaruh Pemahaman Sistem Akuntansi Pengelolaan Keuangan Daerah Terhadap Kinerja Satuan Kerja Pemerintah Daerah. Jurnal Akuntansi dan Keuangan Sektor Publik, Vol.08, No.01, Februari 2007.

Umar Husein, Riset Sumber Daya Manusia Dalam Organisasi, P.T. Gramedia Pustaka Utama, Jakarta. 